ISA

Arboriculture \& Urban Forestry 2016. 42(4): 267-280

\title{
Assessing Municipal Forestry Activity: A Survey of Home-Rule Municipalities in Texas, U.S.
}

\author{
Keith O'Herrin and Patricia Shields
}

\begin{abstract}
Municipal forestry programs in the United States have been the subject of dozens of surveys over the past 40 years that offer valuable insight into what is occurring now and act as a point of reference in the future. Researchers surveyed home-rule municipalities (pop. 5,000 or greater) in Texas, U.S. to assess the commonality of the components of a municipal forestry program, municipal spending on urban forestry, and amount of assistance received from the Texas A\&M Forest Service. Spending on urban forestry in Texas cities averaged USD $\$ 4.88$ per capita overall. Basic tree ordinances, tree boards, non-profit tree advocacy groups, and proactive maintenance cycles were all fairly common. Urban forest management plans and tree inventories were very uncommon. About $70 \%$ of municipal forestry programs are housed in their cities' Parks and Recreation Department, with the majority of the remainder occurring in their Public Works Department. The level of assistance received by municipalities from the Texas A\&M Forest Service is consistent with the budget priorities and mission statement of that organization, which focuses on delivering technical and educational assistance over financial assistance. A lack of recent national trends to compare against greatly hampers understanding the efforts of Texas municipalities relative to other states. However, identifying current trends in Texas offers value to the Texas A\&M Forest Service to understand the effect of their service delivery strategy. Urban foresters and city managers can also use these results to compare themselves against their peers, a common practice in setting municipal budgets and policy.

Key Words. Advocacy; Performance Measurement; Program Evaluation; Tree City USA; Urban and Community Forestry.
\end{abstract}

Assessments of municipal forestry programs describe existing program characteristics, such as staff, expenditures, and other elements to identify where improvement is needed, to allow individual programs to compare themselves against their peers, and to assess the effectiveness of state assistance. An urban forest manager or a city mayor may want to gauge their spending against neighboring cities. A state urban forestry coordinator may want to know where to concentrate budget or the efforts of staff to improve the assistance they provide. There is also value in creating a point of reference-a benchmark-so progress can be analyzed over time.

Municipal forestry programs have been studied at a national scale (Ottman and Kielbaso 1976; Giedraitis and Kielbaso 1982; Kielbaso et al. 1988; Tschantz and Sacamano 1995), a regional scale (Kuhns 1998; Watson 2003), and a state scale (Miller and Bates 1978; Reeder and Gerhold 1993; Thompson and Ahern 2000; Elmendorf et al. 2003; Schroeder et al. 2003; Studer 2003; Treiman and Gartner 2004; Kuhns et al. 2005; Thompson 2006; Ries et al. 2007; Rines 2007). These studies of municipal forestry programs varied greatly in terms of the data they were collecting. Most omit calculations of spending on community forestry activities, including the basic dollars per capita, even though it is well known from its use by the Arbor Day Foundation for the last 40 years. However, four studies of national scope did consistently survey measures of spending on urban forestry, and those studies provide the best available benchmark.

Many of these studies collected demographic data on city foresters and/or the opinions of foresters on various topics. Other studies focused on collecting facts about program composition and assistance from the state to the local level. Except for a few examples, there is considerable inconsistency from study to study, as each was adapted to the needs or interests of the researchers conducting it.

This study used a survey designed to assess the current state of municipal forestry in Texas and set 
a benchmark to track changes over time. Only a few states, such as California, Oregon, and Missouri, have had multiple iterations of municipal forestry program assessments; Texas has never had even one such study devoted to this purpose. Tracking changes (e.g., spending on urban forestry) over time increases the value of these research efforts by measuring the impact of changes in policy or spending.

This is especially important for the State of Texas, whose population is growing very quickly. Texas is the second largest state in the United States by GDP, population, and population growth (U.S. Census Bureau 2013). If the population growth rate seen between 2000 and 2010 continues, Texas will more than double in population to over 55 million residents by 2050 (Potter and Hoque 2013), surpassing California as the most populous state in the U.S. (State of California 2013). This doesn't mean that Texas is a barometer with which to gauge urban forestry activity in other states; what it means that Texas is inherently important because it represents a significant proportion of the land area, population, and economic activity of the United States. Consistently and frequently establishing benchmarks is even more important when changes come more quickly.

The purpose of this research study was to determine the most common components of municipal forestry programs and the level of spending on urban forestry in Texas homerule cities (pop. 5,000 or greater), as well as how much assistance those cities are receiving from the Texas A\&M Forest Service, the agency housing the State of Texas's urban forestry program.

\section{Measuring Municipal Forestry Programs}

Assessment criteria and the selection of program components for this study were distilled from a review of 17 similar studies that assessed urban forestry activity and/or spending at the state, regional, or national level. Criteria and components of municipal forestry programs were also adapted from the USDA Forest Service Urban and Community Forestry Program (Federal UCF) metric, called SOAPs (Staff, Ordinance, Advocacy, and Plan). SOAPs is part of the framework that state urban forestry coordinators use to report urban and community forestry activity at the local level back to the Federal UCF, which is a requirement of each state receiving federal funding for urban forestry.

Based on previous studies, researchers measured three major factors of municipal forestry programs: 1) components of a program, 2) expenditures on urban forestry at the local level, and 3) amount of assistance received from the Texas A\&M Forest Service. Components of a program are the aspects common to a comprehensive municipal forestry program. These components should not be viewed as a measurement of the "impact" a municipal forestry program is having on the community, but rather a measurement of the "capacity for impact." This is because the existence of these program components does not mean a municipality is effectively managing the urban forest, but only that these program components aid in that effort.

Measures of expenditures on urban forestry at the local level have been applied more consistently (though less frequently) in studies reported by the literature than measures of program components or assistance from the state. This allows for some comparison over time. However, measures of spending have never been confined specifically to Texas, which leaves researchers only to compare against national averages, and the last such national benchmark was set in 1994 (Tschantz and Sacamano 1995).

Spending on urban forestry per capita has been used in measuring municipal forestry activity since at least 1974, which is when Ottman and Kielbaso (1976) conducted their nationwide study of municipal forestry programs. This was the same year that the Arbor Day Foundation began the Tree City USA Award program, which utilizes the spending on urban forestry per capita measure as one of the award's requirements. This measure has also been used by Giedraitis and Kielbaso (1982), Kielbaso et al. (1988), Tschantz and Sacamano (1995), Thompson and Ahern (2000), and Kuhns et al. (2005). Spending per capita allows researchers to compare cities of varying sizes against each other by standardizing spending per resident. Adjusting for inflation allows researchers to compare spending rates from various periods in time.

Ottman and Kielbaso (1976), Giedraitis and Kielbaso (1982), Kielbaso et al. (1988), and Tschantz and Sacamano (1995) have all used the "percent of total city budget" measure. The advantage of this measure is that it should be shielded 
from inflation. Spread out over the 40 -year period under comparison in the current study, the rising costs for varying goods and services (such as labor and fuel) should have affected most aspects of municipal government uniformly. This means that inflation can be considered controlled for, so what researchers are really measuring is the prioritization that urban forestry has been given.

The amount of assistance received from the Texas A\&M Forest Service is an important question because state urban forestry programs can be a valuable resource to local programs. Each state has an urban forestry program coordinator at a minimum, paid for through federal funding. Beyond that, state programs vary widely in size and scope as some states supplement federal dollars with their own, while others choose not to (Hauer and Johnson 2008). States must meet certain criteria to be eligible for federal urban forestry funding, including 1) have an urban and community forestry program coordinator, 2) implement volunteer and partnership coordination, 3) create an urban and community forestry council, and 4) develop a state program strategic plan (five-year plan) (Hauer and Johnson 2008). Meeting these four criteria in itself could be considered an accomplishment; however, the intent is to increase urban forestry activity at the local level, which is accomplished largely through funding and supporting state-level programs (O'Herrin 2013).

Few studies have looked at specific examples of assistance provided by a state agency. Ries et al. (2007) conducted a survey of Oregon, U.S., community forestry programs and asked specifically about usage of the state's website, receiving the state's newsletter, and receiving technical advice from the state on-site, over the phone, or by email. This study, in Texas, used three broad categories of assistance, and asked about the quantity of assistance rather than the quality of that assistance. Financial assistance refers to individual instances, such as number of grants or scholarships to attend conferences, rather than a dollar value. Technical assistance could be the number of times advice was received about drafting a new ordinance, implementing a new tree inventory software program, or even a state employee sitting on a hiring panel for a municipal forester position. Educational assistance refers to individual instances of attendance at a conference, or reading periodicals (e.g., newsletters).

\section{METHODS}

\section{The Survey}

The online survey (SurveyMonkey ${ }^{\oplus}$ ) was distributed to 243 cities in Texas thought to be homerule cities. To be a home-rule city in Texas, a community must have a population of 5,000 or greater and meet a few other criteria. In Texas, only home-rule cities can set their own local laws (ordinances). Communities with a population under 5,000 are known as "general law" towns and can only pass ordinances as allowed by the State, which does not include tree ordinances. Since this survey was asking about tree ordinances, only home-rule cities were targeted.

Focusing only on home-rule cities is a limitation of this study, and it would be inappropriate to generalize Texas communities of all sizes based on the results of this research. City size categories, based on population of residents, were created as follows: small (5,000-29,999), medium (30,000-99,999), large $(100,000-499,999)$, and mega $(500,000$ or greater).

The intent of this survey was not a random sample, but rather a survey of as many Texas home-rule cities as possible. Surveys were addressed to the individual in city leadership thought to be responsible for urban forest management, or who could direct the survey to the appropriate respondent. The initial contact list started with individuals known by the Texas A\&M Forest Service to represent their city on matters of urban forestry. This list was supplemented by the inclusion of city employees from the most current membership directories for the Texas City Management Association and the Texas Recreation and Park Society. In many instances, multiple individuals within a given city were contacted (about 440 total individuals were contacted); however, multiple surveys representing the same city were never received.

A link to the survey website was included in an email that served as a cover letter explaining this study. Efforts at contact consisted of the original email and two reminder emails, which included the same link to the survey, over a three-week period, after which the survey was closed. Data analysis of survey results consisted of descriptive statistics and crosstabulation using Excel $^{\oplus} 2013 \quad\left(\right.$ Microsoft $\left.^{\circledR}\right)$. 


\section{Key Categories Measured}

Researchers measured three major factors of urban forestry programs: 1) components of a municipal forestry program, 2) municipal spending on urban forestry activities, and 3) amount of assistance received from the Texas A\&M Forest Service.

\section{Program Components Staff}

The section on staff asked how many full-time equivalent (FTE) employees were dedicated to urban forestry in each community, in increments of 0.25. This employee could be in-house or contracted, or it could be a trained volunteer instead of an employee, although the survey question may have implied it was only referring to in-house employees. In an effort to establish a benchmark on the quantity of staff in Texas dedicated to municipal forestry, this study was simply asking if urban forestry was even $25 \%$ of the time commitment of even one single employee.

\section{Ordinance}

There were four questions to determine the presence of four different tree ordinance components, including a "basic" or "general" tree ordinance, which sets rules for the management of trees on public property. Also included was a question about an ordinance establishing a tree board or requiring a forester position/forestry department be created. The two remaining questions asked about "strong" tree ordinances, which were defined as those regulating trees on private property in some way. These two questions asked about the regulation of the removal of large trees from private property, and whether the city required the protection of trees during construction on private property.

\section{Advocacy}

The advocacy section asked if two distinct types of advocacy groups were present. Those groups were a tree board/commission and a non-profit advocacy group, which regularly facilitates or donates tree planting or tree care on public property.

\section{Plan}

The plan section asked questions about the existence of a comprehensive/master urban forest plan, and if such a plan is mandated by city code.

\section{Inventory and proactive tree maintenance}

This section of this study asked whether a tree inventory existed (including both sample and comprehensive) and whether trees were on a proactive maintenance cycle. Both questions were asked twice-once for street trees and once for park trees.

\section{Position}

The position section asked two questions about the position of the individual in charge of trees on public property. First, how far removed were they from city leadership (e.g., the mayor) defined in steps down the chain of command. For example, if the chain of command is mayor, department head, division manager, urban forester, then that urban forester is three steps removed. And second, in what department are they housed.

\section{Expenditures on Urban Forestry Activity}

This study calculated two measures of municipal spending on urban forestry activity. They were the percent of total city budget spent on urban forestry and spending on urban forestry per capita (per resident). The measurement of percent of total budget spent on urban forestry didn't need to be adjusted for inflation to understand the prioritization that urban forestry has been given in the budget process.

However, the measurement of dollars spent on urban forestry per capita was adjusted for inflation to 2012 dollars (USD\$). The rates of spending per capita, in the current study's results, were compared against $\$ 7.59$ per capita as of $1974, \$ 6.10$ from 1980, \$5.45 from 1986, and \$3.86 from 1994 . The use of a city resident as a unit of measure allowed for an interpretation of urban forestry as a budget priority of a city of any size. The value of this spending measurement was that it allowed researchers to compare two or more cities of any size against each other, apples to apples.

\section{Assistance from the Texas A\&M Forest Service Urban Forestry Program}

Researchers measured three broad categories of assistance local programs received from the Texas A\&M Forest Service. Financial assistance referred to individual instances, such as number 
of grants or scholarships to attend conferences, rather than a dollar value. Technical assistance could be the number of times advice was received about drafting a new ordinance, implementing a new tree inventory software program, or even a state employee sitting on a hiring panel for a new local forester. Educational assistance refers to individual instances of attending a conference or reading periodicals (e.g., newsletters).

No other studies have used the same three broad measurements of assistance; however, at least one study is very similar. From the seven specific examples of assistance that Ries et al. (2007) reported on (all $\mathrm{n}=57$ ), an index was created to match the three broad measurements of assistance used in this study. From Ries et al. (2007), cities that had reported receiving a grant (47\%) was compared against the results of financial assistance from this study. The results of educational assistance from this study was compared against a composite average of $54 \%$ derived from four questions from Ries et al. (2007). Those four questions were listed as 1) the city reported they had visited the Oregon Department of Forestry (ODF) website to access urban forestry information $(55 \%), 2)$ reported receiving a program newsletter or other printed material $(83 \%), 3)$ reported they had sent city staff to an ODF educational workshop (53\%), and 4) reported sending city staff to the annual state urban forestry conference $(25 \%)$. The results of technical assistance from the current study were compared against a composite average of $67 \%$ derived from two questions from Ries et al. (2007). Those two questions were listed as 1) the city reported receiving advice by telephone or electronic mail, and 2) reported receiving an onsite technical assistance visit.

Researchers also compared relative program size between Texas and Oregon by calculating a ratio of state urban forestry employees per state resident. This calculation was based on total state urban population, not just the population of the responding cities. However, Oregon $(81 \%)$ and Texas (85\%) have very similar percentages of their population in urban areas as of 2010 , making comparison reasonable (Iowa State University 2015).

\section{RESULTS AND DISCUSSION:}

Usable surveys representing 79 home-rule cities in Texas were returned for a response rate of 33\%. Table 1 shows that an effort was made to contact at least $66 \%$ of the cities in each size class; however, the small city size class only had a response rate of $21 \%$, and thus these results may not be representative of small home-rule cities.

\section{Components of a Program Staff}

The average number of staff per city was calculated with mega cities standing out at an average of 28.8 staff per city (Table 2). This large amount of staff illustrates the size of municipal forestry programs in cities with over 500,000 residents, relative to smaller cities in Texas. However, the average number of residents per staff member was similar between mega cities $(60,764: 1)$, large cities $(67,427: 1)$, and medium cities $(46,181: 1)$, with a weighted mean of about 55,000 residents per staff member. Small cities had an average 8,608 residents per staff member, although $39 \%$ of small cities responding to this question $(\mathrm{n}=28)$ reported 0 staff.

No standard is known to exist that prescribes an appropriate ratio of city residents per staff member. Additionally, many cities may prefer to rely on fewer in-house staff who manage contractors to perform urban forestry work. This survey question wasn't designed to capture contracted employees. But the existence of a professional staff member is the first program element represented in the SOAPs (USDA 2012). The point is that the individual responsible for the urban forest

Table 1. Home-rule city population sampling rates and response rates by city size class.

\begin{tabular}{lllll}
\hline City size & $\begin{array}{l}\text { \# of cities in size } \\
\text { class (population) }\end{array}$ & $\begin{array}{l}\text { \# of cities } \\
\text { contacted }\end{array}$ & $\begin{array}{l}\text { Percent of cities in size } \\
\text { class contacted (\%) }\end{array}$ & $\begin{array}{l}\text { Number returned } \\
(\text { sample) }\end{array}$ \\
\hline Small (pop. 5,000-29,999) & 250 & 165 & 66 & 35 \\
Medium (pop. 30,000-99,999) & 70 & 50 & 71 & 26 \\
Large (pop. 100,000-499,999) & 26 & 22 & 85 & 14 \\
Mega (pop. 500,000 and greater) & 6 & 6 & 100 & 4 \\
Overall & 352 & 243 & 69 & 64 \\
\hline
\end{tabular}


is a professional with the necessary qualifications (USDA 2012; O'Herrin 2013). So it's a concern that about $27 \%$ of communities responding to this question $(n=62)$ reported 0 staff, indicating they don't have even one employee on staff who dedicated at least $25 \%$ of their time to urban forestrythese were all small- or medium-sized cities.

This survey question wasn't concerned with the qualifications of the staff responsible for managing the urban forest. Rather, researchers were trying to determine if any employee spends even $25 \%$ of their time on trees. The survey found $16(36 \%)$ small and medium cities responding to this question $(\mathrm{n}=47)$ had 0 FTE employees in charge of urban forestry. Of those 16 cities, only two (8\%) had a tree board, and only four (16\%) had a non-profit tree advocacy group. Unless many small and medium Texas cities rely exclusively on contractors to manage their urban forest, there is clearly a gap in small and medium Texas cities that needs to be filled with some type of urban forestry leadership.

\section{Ordinances}

This survey of Texas cities (Table 3) found that $58 \%$ of communities had the basic ordinance that "provides guidance on planting, maintaining, and removing trees on public property. . ." This compares with $62 \%$ of Oregon communities (Ries et al. 2007) that reported they had a municipal tree ordinance or other codes related to trees, and $80 \%$ of California communities (Thompson 2006) that reported they had a "tree ordinance."
Treiman et al. (2011) found that 26\% of city department heads $(\mathrm{n}=521)$ and $50 \%$ of urban foresters $(\mathrm{n}=28)$ in Missouri, U.S. responded that their community had "policies for tree preservation during development and/or construction." The results from Texas showed that $48 \%$ of communities required tree protection on private property during construction activity. Treiman et al. (2011) reported that tree preservation became more common as city size increases, while the current study found that all types of tree ordinances generally became more common as city size increases, with only a slight decline among mega cities (Table 3 ).

Ordinances that extend to private property may often become controversial before, during, and after they are written into local law. This includes ordinances regulating the removal of trees on private property $(43 \%)$ or require trees to be protected during construction on private property (48\%). The basic tree ordinance is referred to here as "basic" because it doesn't regulate trees on private property, and thus passing it would probably not be controversial. Yet only $58 \%$ of cities had passed the basic tree ordinance-hardly more than had passed the more controversial ordinances. Table 3 shows that all the ordinance types generally became more common as city size increased. Smaller communities may not see the need to protect or guide the management of their smaller public tree populations. Additionally, advocacy groups also became more common as city size increased. These advocates may have been playing a large role in the passage of tree ordinances.

Table 2. Characterization of staff by city size class.

\begin{tabular}{llll}
\hline City size & Respondents & $\begin{array}{l}\text { Average number } \\
\text { of staff }\end{array}$ & $\begin{array}{l}\text { Residents per } \\
\text { staff member }\end{array}$ \\
\hline Small (pop. 5,000-29,999) & 28 & 1.5 & 8,582 \\
Medium (pop. 30,000-99,999) & 18 & 1.4 & 46,181 \\
Large (pop. 100,000-499,999) & 12 & 4.9 & 67,427 \\
Mega (pop. 500,000 and greater) & 4 & 28.8 & 60,764 \\
Overall & 62 & 3.9 & 34,675 \\
\hline
\end{tabular}

Table 3. Percent of affirmative responses for tree ordinance components by city size class.

\begin{tabular}{|c|c|c|c|c|c|}
\hline City size & Respondents & $\begin{array}{l}\text { Provide basic } \\
\text { guidance (\%) }\end{array}$ & $\begin{array}{l}\text { Tree board or employee } \\
\text { mandated (\%) }\end{array}$ & $\begin{array}{l}\text { Regulate private tree } \\
\text { removal }(\%)\end{array}$ & $\begin{array}{l}\text { Require tree protection } \\
\text { during construction on } \\
\text { private property }(\%)\end{array}$ \\
\hline Small (pop. 5,000-29,999) & 35 & 40 & 34 & 31 & 37 \\
\hline Medium (pop. 30,000-99,999) & 26 & 85 & 42 & 46 & 54 \\
\hline Large (pop. 100,000-499,999) & 14 & 50 & 64 & 57 & 57 \\
\hline Mega (pop. 500,000 and greater) & 4 & 75 & 50 & 75 & 75 \\
\hline Overall & 79 & 58 & 43 & 43 & 48 \\
\hline
\end{tabular}




\section{Advocacy}

Overall, $41 \%$ of cities responding to the survey had a tree board, and $40 \%$ had a non-profit group that regularly facilitated or donated tree planting or tree care on public property. Non-profit groups became much more common as city size increased, with $58 \%$ of large cities and $100 \%$ of mega cities having at least one non-profit advocacy group. A very similar trend was seen with tree boards as well.

Studies focusing on other states found similar results, including a survey of municipal forestry programs and tree wardens in Massachusetts, U.S., where Rines (2007) found that $41 \%$ of respondents had attained a group that advises/ advocates for the "planting, protection, and/or maintenance of . . community trees." Kuhns et al. (2005) conducted a survey of Utah, U.S., communities and found $23 \%$ of respondents had a "tree board or similar committee." In California, Thompson (2006) found that 58\% of communities had a tree board/commission with "duties or some duties," and that $23 \%$ of communities had a tree advocacy group. Ries et al. (2007) found that $38 \%$ of cities had a "tree advisory committee."

Overall, the number of Texas cities with these two types of advocacy groups is similar to results found representing other states. However, considering the minimal expenses associated with establishing these potentially influential groups, they should be given more attention from advocates and urban foresters. Tree boards are comprised of volunteers and can cost very little to implement except volunteers' time. Non-profit groups may be more complicated to operate by comparison, since a tree board relies on the municipal government for administration and organization, whereas a non-profit group generally does not expect this type of assistance. However, both types of groups are probably under-utilized based on the results of this survey.

\section{Urban Forest Management Plans}

Ries et al. (2007) found that only 9\% of Oregon communities had a "community forest management plan." In a large study of Missouri communities, Treiman et al. (2011) found that $17 \%$ of mayors and city councilors $(\mathrm{n}=824)$ and $17 \%$ of city department heads $(n=521)$ responded that they had a management plan, while only $4 \%$ of urban foresters responded that their city had a management plan $(n=28)$. In Texas, researchers found that urban forestry management plans are very uncommon overall at $13 \%$ and were most common among large cities (33\%). None of the four responding cities over 500,000 (mega cities) had a management plan at the time this survey was distributed (i.e., Austin, Dallas, Houston, and San Antonio), although Austin has since successfully passed one through its City Council thereby finally fulfilling a 22-year-old ordinance mandate. This exemplifies the difficulty often faced when establishing comprehensive/master urban forest plans.

Plans are difficult to implement because the management objectives they contain "should be defined based on an understanding of public attitudes, perceptions, and knowledge, a review of the agents of change, and the expressed needs and concerns of the community (client)" (Miller et al. 2015). This means a thorough planning process is costly in terms of money and/or employee time, and

Table 4. Management plans, inventories, and steps removed from city leadership by spending measures. All currency in USD\$.

\begin{tabular}{|c|c|c|c|c|c|c|c|}
\hline \multirow[t]{2}{*}{ Spending levels } & \multicolumn{2}{|c|}{$\begin{array}{l}\text { Percent with } \\
\text { management plan }\end{array}$} & \multicolumn{2}{|c|}{$\begin{array}{l}\text { Percent with street } \\
\text { tree inventory }\end{array}$} & \multicolumn{2}{|c|}{$\begin{array}{l}\text { Percent with park } \\
\text { tree inventory }\end{array}$} & \multirow{2}{*}{$\begin{array}{l}\text { Steps removed } \\
\text { Average }\end{array}$} \\
\hline & Respondents & $(\%)$ & Respondents & (\%) & Respondents & $(\%)$ & \\
\hline \multicolumn{8}{|l|}{$\$$ per capita } \\
\hline$<\$ 2$ & 30 & 7 & 29 & 17 & 30 & 10 & 3.6 \\
\hline$\$ 2-\$ 9$ & 25 & 16 & 25 & 40 & 24 & 46 & 4.3 \\
\hline$>\$ 9$ & 9 & 44 & 8 & 0 & 8 & 13 & 4.3 \\
\hline Overall & 64 & 16 & 62 & 24 & 62 & 24 & 3.9 \\
\hline \multicolumn{8}{|l|}{ Total $\%$ of budget } \\
\hline$<0.1 \%$ & 21 & 5 & 20 & 10 & 21 & 19 & 3.8 \\
\hline $0.1 \%-1.0 \%$ & 29 & 14 & 29 & 35 & 28 & 36 & 4.0 \\
\hline$>1.0 \%$ & 8 & 50 & 7 & 14 & 7 & 0 & 4.1 \\
\hline Overall & 58 & 16 & 56 & 23 & 56 & 25 & 3.9 \\
\hline
\end{tabular}


may explain why, in Table 4, there appears to be a connection between high spending rates and the presence of management plans.

\section{Inventories and Proactive Tree Maintenance}

Like management plans, inventories of street trees $(20 \%)$ or park trees $(22 \%)$ were also uncommon, whether they are comprehensive or sample inventories. However, the same connection between high expenditure rates and management plans can't be made with inventories (Table 4).

In California, Thompson and Ahern (2000) found that about $55 \%$ of communities had their trees on a regular/systematic tree maintenance cycle, and "less than half of the respondents had a tree inventory of some kind." The results from Texas show a similar trend, where more communities had their trees on proactive maintenance cycles (street trees 47\%; park trees 60\%) than had tree inventories (street trees $20 \%$; park trees $22 \%$ ). In both cases, this means that cities may be flying blind with only rough estimates based on the last maintenance cycle's results to forecast future tree maintenance budget needs.

Like urban forest management plans, performing a tree inventory for the first time or keeping an existing inventory updated can be difficult due to the associated cost, whether paid in money or staff time. Tree inventory software programs are also expensive, and problems may be encountered when trying to integrate new inventory software with existing work order/ call center management software. Factors other than cost may play a role in the prevalence of inventories. Urban foresters in cities with relatively small tree populations might think they can manage effectively without a tree inventory, considering the survey found that inventories became more common as city size increased.

\section{Position}

Urban forest managers in small cities tended to be about two or three steps removed from city leadership. In medium cities, they tended to be about three steps removed. In large or mega cities, they tended to be about four steps removed. The importance of the position of the urban forest manager relative to city leadership has been mentioned several time in the literature, where increased proximity is desirable (Johnson 1982; Thompson et al. 1994; Thompson 2006). Increased proximity to city leadership may improve a program's chances when competing for funding.

However, researchers found that the distance from city leadership increased slightly as spending increased (Table 4). This implies that the urban forester's proximity to city leadership may have less impact on spending rates than other potential factors, such as their ability to communicate effectively, the support their program receives from immediate superiors, and support from advocacy groups (e.g., tree boards or non-profit groups). These results found a clear trend of increased distance between city leadership and urban foresters as city size increases-attempts to decrease this distance may not be the most effective means of securing needed funding.

Johnson (1982) found that parks and recreation departments tended to be more understanding of the mission of urban forestry programs, although programs housed in public works departments tended to have more resources available to them. Thompson and Ahern (2000) conducted a survey of California communities in 1997 and found that almost $70 \%$ of urban forestry programs were housed in parks and recreation departments, and almost $30 \%$ in public works. In a case study of six cities, all with a population over 500,000 and spread across the U.S., Carroll (2003) found that four of those urban forestry programs were in the parks and recreation department (66\%) and two were in public works (33\%). These trends are very similar to the results from the Texas study, which found about $70 \%$ of urban forestry programs were housed in parks and recreation departments, and about $18 \%$ in public works.

However, in Texas, the cities with programs housed in public works were all small cities, with the exception of one medium city, one large city, and Austin (mega) reporting a scenario of shared responsibility between the two departments. Public works departments may often serve as a catch-all in smaller cities, being responsible for whatever tasks and infrastructure don't fit precisely into another department's expertise. This could explain why the survey found several small cities that had less than 1.0 
FTE employee devoted to urban forestry (but still spent money on urban forestry) that housed their programs in the public works department.

\section{Expenditures on Urban Forestry Activity}

Texas is generally considered a low-tax, low-service state (UT-Austin 2009). This means the prevailing political strategy is to avoid raising taxes, which equates to government providing only the most basic services. This is most commonly seen at statelevel politics, but certainly influences local politics as well. This is important to consider when discussing municipal spending on urban forestry activity.

Table 5 shows the results of spending on urban forestry by city size class. Small cities had the highest rate of spending per capita, which may seem biased due to their small populations. This is not the case, as this high rate of spending (relative to size) is consistent with spending as a percent of total city budget second only to large cities. Mega cities in Texas spent less than one tenth of one percent of their budget on urban forestry on average, although their spending per capita just barely met Tree City USA standards at $\$ 2.06$.

The measurement of spending on urban forestry per capita uses dollar values relevant to each period in time. To accurately compare, these values must be adjusted for inflation. Then a downward trend is clearly seen in spending over time until the results of this study from Texas, which is somewhere between the 1994 and 1988 nationwide rates, but still lower than the nationwide rates from 1980 or 1974 .
Spending as a percent of total city budget is shielded from inflation and so direct comparisons can be made without adjusting for inflation. The survey found an overall average of $0.48 \%$ of a city's total budget was spent on urban forestry activities. This was very similar to the 1974 and 1988 nationwide rates, more than the 1994 rate, and less than the 1980 rate (Table 6).

Considering the measurement of spending as a percent of total city budget is shielded from inflation, and the measurement of spending per capita has been adjusted for inflation, it is accurate to say that cities in Texas are spending less now on urban forestry than almost any national trend available. State and municipal budgets suffered large declines in revenue as a result of the economic recession that officially started in late 2007 in the U.S. (Gordon 2012). The effects of this decline in revenue may have had significant effects on spending on urban forestry by municipal governments during the period data were collected by this survey.

However, the national trends available don't include the last 20 years, and so the current state of spending on urban forestry in Texas relative to other states is unknown. Determining the current level of municipal spending on urban forestry in Texas still has value by establishing a benchmark to compare against if a follow-up study is performed in the future.

Another way to consider spending is to compare against the Arbor Day Foundation and Tree City USA Award's requirement of $\$ 2$ per capita, set in

Table 5. Spending on urban forestry in Texas by city size class. All currency in USD\$.

\begin{tabular}{|c|c|c|c|c|}
\hline \multirow[b]{2}{*}{ City size } & \multicolumn{2}{|l|}{$\$$ per capita } & \multicolumn{2}{|c|}{$\%$ of total city budget } \\
\hline & Respondents & Average & Respondents & Average \\
\hline Small (pop. 5,000-29,999) & 26 & $\$ 7.10$ & 22 & $0.62 \%$ \\
\hline Medium (pop. 30,000-99,999) & 23 & $\$ 2.11$ & 21 & $0.29 \%$ \\
\hline Large (pop. 100,000-499,999) & 13 & $\$ 6.21$ & 12 & $0.69 \%$ \\
\hline Mega (pop 500,000 and greater) & 4 & $\$ 2.06$ & 4 & $0.08 \%$ \\
\hline Overall & 66 & $\$ 4.88$ & 59 & $0.48 \%$ \\
\hline
\end{tabular}

Table 6. Spending benchmarks from previous studies compared to the current study. Dollars per capita adjusted for inflation and percent of total city budget as reported. All currency in USD\$.

\begin{tabular}{llll}
\hline Literature & $\begin{array}{l}\text { Year } \\
\text { conducted }\end{array}$ & Scope & $\begin{array}{l}\text { \$ per capita } \\
\text { (2012 dollars) }\end{array}$ \\
\hline Ottman and Kielbaso (1976) & 1974 & Nationwide & $\$ 7.59$ \\
Giedraitis and Kielbaso (1982) & 1980 & Nationwide & $\$ 6.10$ \\
Kielbaso et al. (1988) & 1986 & Nationwide & $\$ 5.45$ \\
Tschantz and Sacamano (1995) & 1994 & Nationwide & $\$ 3.86$ \\
Current survey of Texas & 2013 & Texas & $0.81 \%$ \\
\hline
\end{tabular}


1974 and never modified. Researchers found 53\% of Texas cities met or exceeded this measure. However, if this 1974 rate is adjusted for inflation, it rises to $\$ 9.31$ in 2012 dollars; only about $13 \%$ of respondents from Texas met or exceeded this adjusted value.

Getting an accurate assessment of spending in Texas compared to other states is not currently possible. The national benchmarks are now over 20 years old, and comparing spending in one state against one other state does little to increase understanding of how a state compares nationally on spending on urban forestry because of countless variations between states, including population, area, density, and method of service delivery. On the other hand, comparing one state against the 49 other states would increase understanding of how a state compares nationally on spending on urban forestry, and the need for national benchmarks is clear.

\section{Assistance from the Texas A\&M For- est Service Urban Forestry Program}

The strategy of the Texas A\&M Forest Service is to put the vast majority of their funding into staff positions-staff who can advise, assist, and educate (Johnson 2014) as represented by the levels of technical and educational assistance received, which are much higher than levels of financial assistance received. This is consistent with the state program's mission to "to help build self-sustaining urban forestry and tree care programs. .." (emphasis added).

Texas does offer some financial assistance, and $14 \%$ of cities indicated they had received some. However, the Texas A\&M Forest Service has to be very strategic with their limited budget for this type of assistance, which currently includes scholarships to annual conferences and the Society of Municipal Arborist's Municipal Forestry Institute. The state program has also funded ISA certification in the past. Texas has not offered cost-share grants to communities for projects (e.g., conducting inventories) since about 2008 (Johnson 2014).

Considering the size of Texas, the state program is small with about 11 FTE employees and a total annual budget of about $\$ 900,000$, or only about $4 \%$ of the total spending on urban forestry of all cities responding to this survey. So, increasing financial assistance in the form of grants or scholarships by reducing the number of state FTE employees would not significantly increase spending on urban forestry at the local level.

Ries et al. (2007) found 47\% of communities in Oregon reported receiving financial assistance, whereas the Texas results found $14 \%$ had received financial assistance (Table 7). The study by Ries et al. (2007) was conducted in 2004 when the State of Oregon was receiving almost 50\% more funding than they did in 2014 from the Federal Urban and Community Forestry Program (Ries 2014). Oregon is currently conducting a ten-year follow-up survey to Ries et al. (2007), and the expectation is that the amount of financial assistance received by communities will have declined significantly (Ries 2014).

Technical assistance refers to advice received by locals from state employees, such as on implementing an ordinance. Educational assistance includes attendance at conferences or seminars and reading publications or outreach materials. Oregon communities reported receiving more technical assistance (67\%) than Texas communities (52\%).

Educational assistance was very similar between the two states (Oregon 54\%; Texas 49\%). Both states maintain a website with valuable information on arboriculture and urban forestry, a newsletter, and host/contribute significantly to a state-level annual conferenceon arboricultureand urban forestryissues.

Oregon has 1.4 million residents per one state FTE employee, while Texas has 2.4 million residents per one state FTE employee. Therefore, state community forestry program employees in

Table 7. Percent of cities receiving assistance at least once in 2012 , and the average number of times assistance was received from the state by city size class.

\begin{tabular}{|c|c|c|c|c|c|c|c|c|c|}
\hline \multirow[b]{2}{*}{ City size } & \multicolumn{3}{|c|}{ Financial assistance } & \multicolumn{3}{|c|}{ Technical assistance } & \multicolumn{3}{|c|}{ Educational assistance } \\
\hline & Respondents & Percent & $\begin{array}{l}\text { Assists } \\
\text { per year }\end{array}$ & Respondents & Percent & $\begin{array}{l}\text { Assists } \\
\text { per year }\end{array}$ & Respondents & Percent & $\begin{array}{l}\text { Assists } \\
\text { per year }\end{array}$ \\
\hline Small (pop. 5,000-29,999) & 25 & $8 \%$ & 0.1 & 27 & $33 \%$ & 1.1 & 25 & $32 \%$ & 0.7 \\
\hline Medium (pop. 30,000-99,999) & 13 & $8 \%$ & 0.2 & 17 & $53 \%$ & 1.5 & 18 & $56 \%$ & 1.4 \\
\hline Large (pop. 100,000-499,999) & 9 & $33 \%$ & 0.6 & 10 & $90 \%$ & 4.0 & 11 & $73 \%$ & 2.2 \\
\hline Mega (pop 500,000 and greater) & 3 & $33 \%$ & 0.7 & 4 & $75 \%$ & 3.8 & 3 & $67 \%$ & 3.7 \\
\hline Overall & 50 & $14 \%$ & 0.2 & 58 & $52 \%$ & 1.9 & 57 & $49 \%$ & 1.4 \\
\hline
\end{tabular}


Texas are responsible for $40 \%$ more state residents than their Oregon counterparts, which may partly explain how Oregon provides 15\% more technical assistance and 5\% educational assistance. Overall, 52\% of respondents in Oregon and 55\% in Texas receive at least some type of assistance whether it be financial, technical, or educational.

The results from the Texas study are representative of the state program's mission statement and budget priorities. The programs in Texas and Oregon are very similar in that as their funding fluctuates over time, they allow financial assistance to decline in favor of preserving staff who can provide technical and educational assistance. Texas is providing assistance to about half of the home-rule cities in Texas, and Oregon is providing assistance to about half of the incorporated cities in Oregon. Both states are adapting well to the digital age with increased efficiency by utilizing the internet and digital communication to provide technical and educational assistance to communities spread out over vast areas, though face-to-face contact may be suffering. However, both states take a regional representative approach to providing assistance and facilitate regional workshops, in addition to their annual statewide conference, which may increase opportunities for face-to-face networking.

\section{CONCLUSIONS}

A lack of consistency across studies is clearly evident when reviewing studies of municipal forestry programs. This includes how and with whom the information is shared, what information is collected, the frequency of repetition, and whether repetition occurs at all. As a result, direct comparison of the results of this survey against other studies that surveyed other states was difficult or sometimes impossible. There is a strong need for coordination of these types of studies so that states can compare themselves against their peers, as well as track their own progress over time. The basic level of information presented in this study-What do we have now? - is the starting point of any process to plan for improvement.

Despite the inability to easily compare these results from Texas directly against other studies, these results are useful to researchers and important to Texas practitioners now. Home- rule municipalities in Texas have a great deal of authority allotted to them by the state government to regulate within their jurisdiction, and this is seen in the number of cities that had ordinances regulating tree removal on private property $(43 \%)$ or requiring the protection of trees during construction on private property (48\%). Although, it was disappointing that only $58 \%$ of cities had the basic ordinance to regulate public trees, which is usually an uncontroversial ordinance. Tree advocates should take note that their support probably means the difference to enacting even this most basic tree ordinance, in addition to more controversial ordinances that regulate trees on private property.

Even without another state to compare against, it's a concern that about one quarter of responding cities don't even have 0.25 FTE employees dedicated to urban forestry. All those cities without urban forestry staff had a population of 43,000 or less, so the lack of staff is probably a result of budget prioritization, or a lack of urban forestry advocacy. The effect of budget constraints is also seen in the generally downward trend in spending compared to national benchmarks, and the lack of management plans (13\%).

Comparing the effectiveness of the Texas A\&M Forest Service against programs in other states is difficult because there is recent data available for only one other state. Comparison against recent nationwide data would be much more useful. Here, researchers can only conclude that service delivery in Texas is fairly consistent with Oregon.

This study was designed to be repeated in the future so changes can be tracked over time, emulating successful efforts at consistent repetition in California, Missouri, and Oregon. However, the results of this study have value now to many different groups. Recommendations based on the results and based on information discovered while conducting this study are as follows:

The Arbor Day Foundation should consider a gradual, phased approach to updating the dollars per capita spending requirement of the Tree City USA Award. Once adjusted for inflation, the updated rate is more than four times the current requirement, which was set over 40 years ago and has never been updated. This would provide a more realistic (mod- 
ern) budget expectation for municipalities that use Tree City USA requirements as their bar for measuring expenditures on urban forestry.

National benchmarks via nationwide surveys, such as Ottman and Kielbaso (1976), are critically important and should be established every 5 or 10 years.

State Urban Forestry Coordinators should begin performing state-specific surveys as a matter of course and share the results with their clients and their peers.

The Texas A\&M Forest Service should continually reevaluate its budget priorities and the types of assistance it distributes (financial versus technical and educational). However, sacrificing staff positions in favor of increased financial assistance offered to communities is probably a poor strategy. This would almost certainly have a large negative impact on the delivery of technical and educational assistance, while having a negligible increase in spending on urban forestry at the local level.

Texas city managers and others in city leadership should review the results of this study to assess themselves against their peers. This type of evaluation is a very common practice in city management whenever data is accessible.

Urban forest managers and city leadership need to assign higher priority to management plans and inventories. Both components are labor intensive and/or costly and both require recurring inputs to maintain relevancy, but are worth the effort because both components may often result in increased attention, support, and funding for urban forestry management.

The presence of advocacy groups in Texas is roughly average compared to other states, but should still receive increased attention. Tree boards and non-profit groups can advocate for urban forestry in ways that employees can't, and both may require little or no tax dollars to implement.

Acknowledgments. We wish to acknowledge the ISA Texas Chapter of the International Society of Arboriculture for awarding a scholarship to Keith O'Herrin while conducting this research as a master's student at Texas State University.

\section{LITERATURE CITED}

Carroll, P. 2003. Urban forestry in large cities: 'Cutting Edge' or 'Cutting Out.' pp. 18-20. In: Proceedings of the 2003 National Urban Forest Conference. San Antonio, Texas: American Forests, Washington, D.C.

Elmendorf, W.F., V.J. Cotrone, and J.T. Mullen. 2003. Trends in urban forestry practices, programs, and sustainability: Contrasting a Pennsylvania, U.S. study. Journal of Arboriculture 29(4):237-248.

Giedraitis, J.P., and J.J. Kielbaso. 1982. Municipal Tree Management. Urban Data Service Report. Washington, D.C.: International City Management Association.

Gordon, T. 2012. State and local budgets and the great recession. Stanford, CA. Stanford Center on Poverty and Inequality.

Hauer, R.J., and G.R. Johnson. 2008. Approaches within the 50 United States to meeting federal requirements for urban and community forestry assistance programs. Arboriculture \& Urban Forestry 34(2):74.

Iowa State University. 2015. Urban Percentage of the Population for States, Historical. Accessed January 2015. <www.icip.iastate. edu/tables/population/urban-pct-states>

Johnson, C. 1982. Political and administrative factors in urban forestry programs. Journal of Arboriculture 8(6):160-163.

Johnson, P. 2014. Semi-structured Telephone Interview. Conducted by Keith O’Herrin, June 2014.

Kielbaso, J.J., B. Beauchamp, K. Larison, and C. Randall. 1988. Trends in Urban Forestry Management. Baseline Data Report. Washington, D.C.: International City Management Association.

Kuhns, M. 1998. Urban and community forestry in the intermountain west. Journal of Arboriculture 24(5):280-85.

Kuhns, M., B. Lee, and D.K. Reiter. 2005. Characteristics of urban forestry programs in Utah, U.S. Journal of Arboriculture 31(6):285-295.

Miller, R.W., and T.R. Bates. 1978. National implications of an urban forestry survey in Wisconsin. Journal of Arboriculture 4:125-127.

Miller R.W., R.J. Hauer, and L.P. Werner. 2015. Urban Forestry: Planning and Managing Urban Greenspaces, third edition. Waveland Press. 560 pp.

O'Herrin, K. 2013. A Description of Texas Municipal Forestry Programs: How Critical Program Elements Vary According to City Size, Expenditures, and Assistance from the State. Masters of Public Administration, Applied Research Project. San Marcos, TX: Texas State University.

Ottman, K., and J.J. Kielbaso. 1976. Managing Municipal Trees. Urban Data Service Report. Washington, D.C.: International City Management Association.

Potter, L.B., and N. Hoque. 2013. Texas Population Projections, 2010 to 2050. State of Texas, Office of the State Demographer.

Reeder, E.C., and H.D. Gerhold. 1993. Municipal Tree Programs in Pennsylvania. Journal of Arboriculture 19(1):12-19.

Ries, P.D. 2014. Semi-structured Telephone Interview. Conducted by Keith O’Herrin, June 2014.

Ries, P.D., A.S. Reed, and S.J. Kresse. 2007. The impact of statewide urban forestry programs: A survey of cities in Oregon, U.S. Journal of Arboriculture \& Urban Forestry 33(3):168-175.

Rines, D.M. 2007. A Survey of Tree Wardens to Assess Urban and Community Forestry Performance in Massachusetts (USA). M.S. Forestry, Thesis. Amherst, MA: University of MassachusettsAmherst. 
Schroeder, H.W., T.L. Green, and T.J. Howe. 2003. Community tree programs in Illinois, U.S.: A statewide survey and assessment. Journal of Arboriculture and Urban Forestry 29 (4):218-225.

State of California. 2013. New Population Projections: California to Surpass 50 Million in 2049. Press Release. State of California, Department of Finance.

Studer, N. 2003. Urban forest program development in Washington State municipalities. pp. 21-23. In: Proceedings of the 2003 National Urban Forest Conference. San Antonio, Texas: American Forests, Washington, D.C.

Thompson, R., N.H. Pillsbury, and R.J. Hanna. 1994. The Elements of Sustainability in Urban Forestry. Urban Forest Ecosystems Institute California Polytechnic State University.

Thompson, R.P. 2006. The State of Urban and Community Forestry in California: Status in 2003 and Trends Since 1988. Technical Report 13. San Luis Obispo, CA: Urban Forest Ecosystem Institute, California Polytechnic State University.

Thompson, R.P., and J.J. Ahern. 2000. The State of Urban and Community Forestry in California: Status in 1997 and Trends Since 1988. Technical Report 9. San Luis Obispo, CA: Urban Forest Ecosystem Institute, California Polytechnic State University.

Treiman, T., and J. Gartner. 2004. Community forestry in Missouri, U.S.: Attitudes and knowledge of local officials. Journal of Arboriculture 30(4):205-213.

Treiman, T., N. Kuhn, and M. Tomlin-McCrary. 2011. Urban Forestry in Missouri Communities: Attitudes and Knowledge of Local Elected Officials, Department Heads and Urban Forester. Missouri Department of Conservation.

Tschantz, B.A., and P.L. Sacamano. 1995. Municipal tree management in the United States. In: Proceedings of the 7th National Urban Forest Conference. New York, New York.

U.S. Census Bureau. 2013. 2010 Census Urban and Rural Classification and Urban Area Criteria. Accessed 18 August 2013. <www. census.gov/geo/reference/ua/urban-rural-2010.html>

USDA Forest Service Urban and Community Forestry Program. 2012. Personal communication with Beattra Wilson regarding the SOAP metrics.

UT-Austin College of Liberal Arts. 2009. Texas Political Culture: Low Taxes, Low Services Political Culture. Texas Politics. Accessed July 2014. <http://texaspolitics.laits.utexas.edu/10_2_1.html>

Watson, T.W. 2003. Evolution of Municipal Urban Forestry in the South. 2003 National Urban Forest Conference Proceedings; San Antonio, Texas, 14-17 September 2003.

\author{
Keith O'Herrin (corresponding author) \\ Ph.D. Candidate - Urban Forestry \\ Department of Forest Resources and Environmental \\ Conservation \\ Virginia Tech \\ Cheatham Hall \\ 310 W Campus Drive \\ Blacksburg, Virginia 24061, U.S. \\ koherrin@vt.edu
}

Patricia Shields, Ph.D.

Professor

Department of Political Science

Texas State University

San Marcos, Texas 78666, U.S.

ps07@txstate.edu
Résumé. Les programmes de foresterie municipale aux ÉtatsUnis ont fait l'objet de douzaines d'études, au cours des 40 dernières années, offrant des informations précieuses sur ce qui se passe actuellement et afin de servir comme élément de référence pour le futur. Les chercheurs ont évalué des municipalités autonomes (population de 5000 ou plus) au Texas, États-Unis, afin d'identifier des composantes communes du programme de foresterie municipale, des budgets municipaux attribués à la foresterie urbaine et du niveau du soutien reçu du Texas A\&M Forest Service (Service des forêts du Texas A \& M). Les dépenses en foresterie urbaine dans les villes du Texas sont en moyenne de $\$ 4,88$ USD par habitant. La réglementation sur les arbres, les comités décisionnels de forêt urbaine, les groupes sans but lucratif de défense des arbres et les programmes d'entretien arboricole cyclique étaient plutôt courants. Les plans de gestion de la forêt urbaine et les inventaires d'arbres étaient très rares. Environ $70 \%$ des programmes municipaux de foresterie relevaient du Service des parcs et des loisirs tandis qu'une majorité des autres se retrouvaient au Service des Travaux publics. Le niveau de soutien reçu par les municipalités de la part du Service des forêts du Texas A \& M est cohérent avec les priorités budgétaires et le cahier des charges de cette organisation, qui se concentre davantage sur une assistance technique et pédagogique plutôt qu'une aide financière. La méconnaissance des tendances nationales récentes gêne considérablement la comparaison des efforts des municipalités du Texas en lien avec celles d'autres États. Cependant, l'identification des tendances actuelles au Texas est d'une certaine utilité au Service des forêts du Texas A \& M afin de bien comprendre l'effet de leur stratégie de prestation des services. Les forestiers urbains et les gestionnaires municipaux peuvent également utiliser ces résultats pour se comparer à leurs pairs, une pratique courante dans l'établissement des budgets et des politiques municipales.

Zusammenfassung. Kommunale Forstprogramme in den Vereinigten Staaten sind in den letzten vierzig Jahren Thema in Duzenden Umfragen gewesen, die einen wertvollen Einblick liefern, was aktuell erscheint und was als Referenzpunkt für die Zukunft geeignet sein kann. Die Forscher untersuchten selbst verwaltete Kommunen mit $>5000$ Einwohnern in Texas, USA, um die Gemeinsamkeiten der Komponenten eines kommunalen Forstprogrammes, die kommunalen Ausgaben für Grünanlagen und die Menge an Assistenz, die von dem Texas A\&M Forest Service geboten wird, zu untersuchen. Die kommunalen Ausgaben für Grünanlagen in texanischen Städten lagen durchschnittlich bei $\$ 4,88$ pro Kopf. Einfache Baumschutzsatzungen, Baumgremien, gemeinnützige Pro-Baum-Gruppen und proaktive Pflegezyklen waren überall vorhanden. Urbane Forstverwaltungspläne und Baumkataster waren sehr selten. Etwa 40 \% der kommunalen Forstprogramme sind bei den lokalen Grünflächenämtern untergebracht, während die Mehrzahl im Bereich für Öffentlichkeitsarbeit angesiedelt ist. Der Grad an erhaltener Unterstützung durch den Texas A\&M Forest Service ist konsistent mit den Prioritäten des Budgets und der Kernaussage über die Mission dieser Organisation, welche vor der finanziellen Unterstützung auf die Bereitstellung von technischer Assistenz und Unterstützung bei der Fortbildung fokussiert. Ein Mangel an gegenwärtigen nationalen Trends zum Vergleichen mit anderen Bundesstaaten behindert das Verständnis für die Bemühungen texanischer Städte. Trotzdem bietet die Identifizierung der gegenwärtigen Trends in Texas wertvolle Informationen für den Texas A\&M Forest Service, die Auswirkungen ihres Service-Angebotes besser zu verstehen. Urbane Forstleute und Stadtplaner können diese Ergebnisse ebenso nutzen, um sich mit ihren Mitstreitern zu vergleichen, eine übliche Praxis bei der Entwicklung kommunaler Haushalte und Politik.

Resumen. Los programas municipales forestales en los Estados Unidos han estado sujetos a decenas de encuestas en los últimos 40 años que ofrecen información valiosa sobre lo que está ocur- 
riendo ahora y actúan como un punto de referencia en el futuro. Los investigadores examinaron los municipios (población 5,000 o mayor) en Texas, EE.UU. para evaluar los componentes de un programa municipal forestal, el gasto municipal en la dasonomía urbana y la cantidad de ayuda recibida del Servicio Forestal de Texas A\&M. El gasto en la dasonomía urbana en las ciudades de Texas promedió USD \$ 4.88 global per cápita. Las ordenanzas básicas de árboles, recomendaciones de árbol, grupos de defensa del árbol sin fines de lucro y los ciclos de mantenimiento proactivo eran bastante comunes. Los planes de manejo forestal urbano y los inventarios de los árboles eran poco frecuentes. Alrededor del 70\% de los programas forestales municipales están alojados en el departamento de parques y recreación de su ciudad, el resto se producen en su departamento de obras públicas. El nivel de la asistencia recibida por los municipios de la A\&M de Texas Forest Service consistente con la misión y las prioridades del presupuesto comunicado de esa organización, que se centra en la prestación de asistencia técnica y educativa sobre la ayuda financiera. A falta de las tendencias nacionales recientes en gran medida para comparar con la comprensión de que constituye un obstáculo a los esfuerzos de los municipios de Texas en relación a otros estados. Sin embargo, la identificación de las tendencias actuales en Texas ofrece valor al Servicio Forestal de Texas A \& M para entender el efecto de su estrategia de prestación de servicios. Los dasónomos urbanos y autoridades municipales también pueden utilizar estos resultados para compararse con sus compañeros, una práctica común en la fijación de los presupuestos y las políticas municipales. 